\title{
Correlation of Communication and Compensation and Benefits on Employees Performance Mediated by Motivation: Research on Companies Merger and Acquisition in Indonesia in Oil and Natural Gas Industry
}

\author{
Amalia Nur Kucaladevi ${ }^{1} \square$ Sofyan Hernando ${ }^{2}$, Dodi Thaufik Fathurokhman ${ }^{3}$ and Tengku Mohd. Khairal \\ Abdullah ${ }^{4}$ \\ ${ }^{1234}$ Business Management, Binus Business School, Jakarta, Indonesia \\ $\square$ Corresponding Author: Amalia Nur Kucaladevi, E-mail: kucaladevi@gmail.com
}

\begin{abstract}
ARTICLE INFORMATION
Received: 01 September 2021

Accepted: 28 October 2021

Published: 07 November 2021

DOI: 10.32996/jbms.2021.3.2.18

\section{KEYWORDS}

M\&A, communication, compensation \& benefits, motivation, employees performance

\section{ABSTRACT}

Merger and Acquisition (M\&A) is a common business practice in the twenty-first century. In M\&A, human resource is the key to its success especially to create valueadded for the company. Thereby, employees' performance shall be understood by the company towards its objectives. The purpose of this research is to examine what factors have potential effects on employees' performance in the context of companies after acquisition. Factors analyzed are communication and compensation \& benefits, using motivation as a mediation factor on the relation between the factors to the employee's performance. Quantitative method is used in this research, whereas the data is collected by online questionnaire to 215 respondents of employees in four oil and gas companies in Indonesia after their acquisition by the state-owned enterprise within the period 2015-2018. Data analysis is processed with the help of SPSS of path analysis and Sobel test to test the hypotheses. Findings show that communication and compensation \& benefits have a significant correlation on employees' performance. In addition, Motivation as a mediation variable also intervenes the correlation of communication and compensation \& benefits to employees' performance.
\end{abstract}

\section{Introduction}

The primary objectives of all companies in the market are profitability and positioning to create and maximize return for the shareholders. One internal growth can be achieved by M\&A (Ghosh and Das, 2003). In the late 20 th century, world integration and economic globalization is getting much stronger where companies' M\&A become a globalization trend and many used it for their business organization restructuring. The company deals with $M \& A$ driven by strategic business motivation which principle is economic factors (Poddar, 2019). A report published by Duff \& Phelps Singapore Pte Ltd (2016) stated that a number of M\&A deals and values in Indonesia peaked in 2012, and then experience a downturn seen from the number of transactions and deals, in particular within 2013-2015. However, the number of M\&A transactions had increased and the deals had recovered significantly in 2016 as dominated by domestic transactions from the economic "package" introduced by President Joko Widodo to increase competitive edge and attract investment (Timmerman, 2017). According to Tegos (2016), such an increase is expected to continue in 2017 in view of pervasive restructuring in the technological-related industry.

The company's human resources, the employees, their roles are important to ensure the company's success, especially the companies formed by M\&A. Employees roles could create value add for the company. The importance of employees' performance shall be learned by the company to develop an objective and consistent evaluation of their employees. Management communication to employees is significantly important in any M\&A process and after M\&A is completed. Research by Ge \& Cao (2014) also highlights this issue. Muda, Rafiki, and Harahap (2013) stated that a business organization could have better coordination between team through effective communication, otherwise, lack of communication reflect problems in business operation or unnecessary differences between members. Compensation \& benefits, on the other hand, shall also be highlighted

Copyright: (c) 2021 the Author(s). This article is an open access article distributed under the terms and conditions of the Creative Commons Attribution (CC-BY) 4.0 license (https://creativecommons.org/licenses/by/4.0/). Published by Al-Kindi Centre for Research and Development, London, United Kingdom. 
by the acquiring company. Compensation practices to create better employees' performance is designed to improve their productivities as a result of higher accountability, whilst observing different performances shown by the employees (Samnani $\&$ Singh, 2014). It is without a doubt that employees' performance relies on their motivation in their occupation. Motivation is also having an important role in achieving an organization's objectives. Each employee is a unique individual and has different motives. Even though the company couldn't do much about motives different, the company could still understand their basic motive to maintain their high performance which will empower them to achieve the company's objectives.

Research on employees' perception on communication and compensation \& benefits to their performance especially those who work in oil and gas company after the acquisition is few in Indonesia, as well as research which uses Motivation variable as the mediator between communication and compensation \& benefits on employees performance. Therefore, the purposes of this research are:

1. Whether Communication has a direct correlation to Employees Performance in oil and gas company after acquisition in the period 2015-2018?

2. Whether Compensation \& Benefits has a direct correlation to Employees Performance in oil and gas company after acquisition in the period 2015-2018?

3. Whether Motivation has a mediation effect in the correlation between Communication, Compensation \& Benefits on Employees Performance?

\section{Literature Review \& Hypothesis \\ 2.1 Employees Performance}

Mwebi and Kadaga (2015) argued that employees' performance refers to their attitude towards their works. There are several basics or characteristics that can be used to determine employees' attitudes towards their works, which are different from one field to another. Employees with larger control over their schedule have a tendency to show higher involvement, commitment, retention, and satisfaction (Muchiti dan Gachunga, 2015). From Andreani (2016), employees' performance is a result of their performance within a period based on the responsibility authorized by the company. Higher employee's performance describes their capability to make a contribution by their performance, therefore, showing attitude in line with the company's objectives, and has positive impacts on the company's productivity.

Research by Bhatia \& Balani (2015), shows that effective internal communication has a significant role in the higher level of employees performance. Widiani et al., (2019) stated that whether compensation is positively and significantly correlated with employees' performance. The higher compensation received by the employees, the higher their performance.

\subsection{Communication}

Communication is an important point because all processes from planning to the organizing of an organization may be implemented according to plan if it is well communicated. Communication may be defined as a process that conveys an idea, information, and understanding from one to another with the expectation that they could interpret it accordingly (Mangkunegara, 2005). Organizational communication in general discuss function and relationship structure between people in an organization, there is a limitation on information flow in a network that relies on each other, such as horizontal and vertical flow of communication (Sosrowidigdo, 2020).

Bhatia \& Balani (2015), shows that effective internal communication is significantly important to increase employees performance. Therefore, the organization shall articulate its policies that focused on the development of an effective internal communication system to improve employees' performance. Hee \& Qin (2019) with their research on the correlation of communication on employees' performance in property developer company shows that top down and horizontal communication having positive significant correlation on employees performance, in which top down communication is expected would share information between superordinate and with their subordinate. Top-down communication often reduces any unnecessary loads and improves employees' performance in an organization. Whereas horizontal communication enables a higher level of teamwork between staff and reflects higher performance in their works. Research by Amah (2016) concluded that there is a significant correlation between organization internal communication and employees performance that it is important to achieve a higher level of employees performance in terms of efficiency and effectiveness, where top-down communication could affect the roles and the performance and as media to involve the employees in decision making, increase capacities and support the employees to shows more effective and efficient performance. Whereas bottom-up communication helped to maintain cooperative and vertical structural understanding, thereby enabling a more harmonious occupational environment to achieve employees' efficiency and effectiveness. Based on the previous researches, the author proposed this hypothesis: 
Hypothesis 1. Communication is significantly correlated on Employees Performance

\subsection{Compensation \& Benefit}

Compensation can be defined as any kind of appreciation or reward in return for employees' contribution to their organization as given to the company. Compensation has two main components according to Dessler (2006), which are (1) Direct payment such as salary or wages, incentives, and bonuses and commissions; (2) Indirect payment such as health benefits, insurance, financial gain, and paid leaves.

Financial remuneration such as retention incentives had long been considered as an antidote to maintaining potential employees during M\&A deals. In many M\&A, compensation \& benefit is included as a retention plan, and the amount of money is increased to retain the employees often considered as a part of the deal. The company wanted to believe that the retention incentive to stay with the surviving company is sufficient to make them stay. However, retention incentives may be started only to build a bridge that recovers the employee's trust by buying some time. Financial remuneration alone would not build employees' performance in the long term. The company shall gain their employee's trust back. Otherwise, after retention incentives are paid, the employees might consider better alternatives. Furthermore, the amount paid to them as retention incentives, when it ceased or discontinued, would only create temporary stability (Kivuti, 2013).

Sufficient compensation to the roles and responsibilities of a company, and pursuant to the government regulation will affect the employees, thereby improving their performance (Candradewi \& Dewi, 2019). Widiani et al., (2019) stated in their research that compensation shows a positive and significant correlation on employees' performance that the bigger compensation received by the employees, the higher their performance. Hameed et al., (2014) in his research stated that compensation shows a positive correlation on employees performance, such compensation as salary, and direct compensations such as health insurance, pension fund, annual leaves, and paid leaves, and maybe a discount given to their employees in the case of food-related companies. Research by Aktar et al. (2012) shows that there is a positive correlation between rewards and employees performance. There are two factors included in extrinsic rewards such as base salary and performance bonus. Base salary is a highly significant factor that affects employees' performance relative to a performance bonus. Both are positive significant factors that affect employees' performance. There are four factors of intrinsic rewards such as acknowledgment, access to education, challenging works, career advancement. Among the four factors, it is challenging works that affect performance employees highly significant. Previous researches are the basis for the following hypothesis:

Hypothesis 2. Compensation and Benefit significantly correlated on Employees Performance

\subsection{Motivation}

The term Motivation comes from Latin which is movere means to move. Hanafi and Yohana (2017) define motivation as an effort to determine employees' needs and help to achieve them by the uninterrupted process. Motivation at its base serves the purpose of easier attitude and power which enable an individual to take actions towards certain objectives (Shahzadi et al., 2014).

Employees need to be motivated, the purpose is to maximize their capabilities and skills to achieve the company's demand. An individual will feel that their works are had if their motivation is low. Employees will consciously perform in their field with the right motivation. Good organization is built on motivated employees to serve the company or organization (Hamali, 2018).

M\&A is expected to have a differential effect on the employee's motivation level (Kivuti, 2013). The acquiring company acknowledged that M\&A created opportunities window in employees selection. M\&A is used as a mechanism to dismiss employees no longer productive from lack of motivation, and then increase the employee's skills, and recruit new employees with more skills according to the surviving company's needs which expect higher motivation. Further motivation could be achieved through management programs such as management transition completion, improving inter-entities communication, and facilitating complex integration (Tanriverdi \& Venkatraman, 2005). Employees' motivation is the most important element for all organizations to have excellent achievement both in public or private sectors (Chintallo \& Mahadeo, 2013).

Experts had identified two different motivations, intrinsic and extrinsic. Both motivations are believed to have a direct implication to performance because it needs higher energy level, concentration, and determination as stated by the previous research such as Maduka dan Okafor (2014). Research by Kiruja E.K. and Mukuru, E. (2018) stated when the motivation is high, the employee's performance is high and thereby motivation is an important predictor of employees' performance in an intermediate-level public technical institution in Kenya. Some employees are poorly motivated because of a lack of acknowledgment for good performance and without any feedback after their works are completed, thereby rewards and feedback really helped to improve employees' motivation in their works. This is supported by Abdulsalam \& Mawoli's (2012) research on motivation and performance of academic 
staff in a state university in Nigeria, which stated that motivation has a significant correlation on the performance of academic staff but without a significant correlation on academic staffs research performance. Implicitly, university lecturers shall be motivated sufficiently to facilitate effective knowledge transfer to their students and to improve educational standards in universities in Nigeria. Research by Shahzadi et. Al (2014) examines the relationship between motivation and employees' performance, it described that the employees are motivated by autonomy and freedom given to them to work, which will affect their spirits and performance.

Candradewi \& Dewi (2019) in their research stated that motivation could mediate partially the relationship between compensation and employees performance, therefore the company needs to improve employees' motivation for higher performance. This research and previous researches are conducted in the public sector of several industries, but it did not specify to oil and natural gas industry. In addition to the research by Chandradewi \& Dewi (2019), no other research examines motivation as a mediation variable. It is for these reasons, the author proposes the following hypotheses:

Hypothesis 3. Motivation significantly correlated on Employees Performance

Hypothesis 4. Motivation mediate the relationship between the Communication on Employees Performance

Hypothesis 5. Motivation mediate the relationship between Compensation and Benefits on Employees Performance

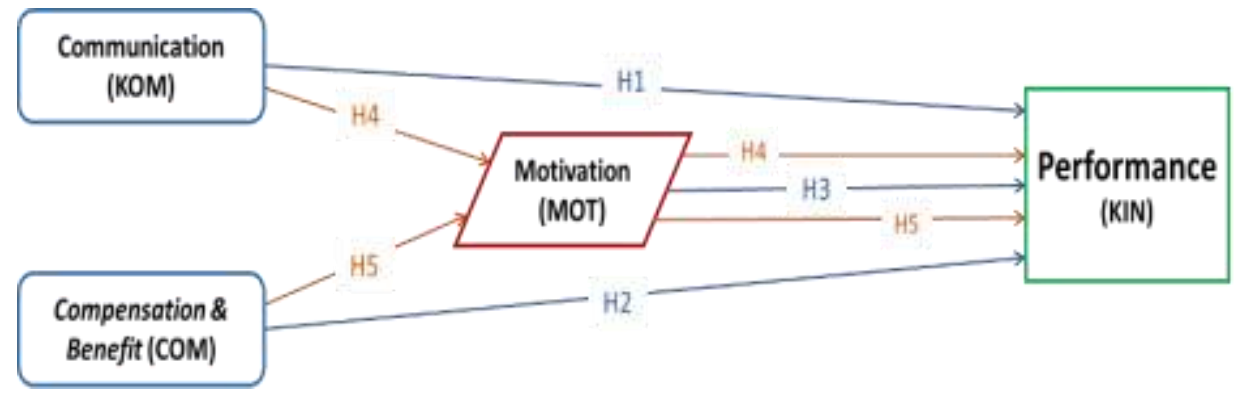

Figure 1. Conceptual Framework

The framework of this research is shown in Figure 1. According to the previous researches, the author proposed that communication and compensation \& benefits could affect employees' performance directly. In addition, we propose that motivation could mediate the relationship between communication and compensation \& benefit performance.

\section{Methodology}

In this research, the sampling method used non-probability sampling by purposive sampling approach, because the target of research respondents is according to the several criteria determined by the author and according to the research objectives. Research objects are communication and compensation \& benefit, and employees motivation and research subjects are employees who work with foreign oil and natural gas companies that had been acquired by state-owned oil and gas enterprises in 2015-2018, where the unit of analysis is individual. No other specific criteria limit the subject in addition to the stated above, where including subject is comes from various position levels (operators - managerial staffs), sex, department/office, and works location (land or offshore platform). This research involved four companies with a total population of as much as 1,248 full-time employees. The number of samples needed in this research is calculated using the Slovin equation, $=\frac{N}{1+N e^{2 \prime}}$ and with a 95\% confidence level (e), as many as 303 samples are collected.

Data collection used the survey method from the end of 2020 to February 2021 (about 60 days). Survey used questionnaire distributed through electronic media such as questionnaire link in electronic mail or messaging application in social media ( $>350$ questionnaires), thereby it reached the respondents who work in the office and in the field (land or offshore platform). The questionnaire asks closed questions and used the Likert Scale 1-5. The total number of respondents is 215 questionnaires or $71 \%$ of the total sample requirement. The author is aware of such a lower sample population and understood it as because the people who asked to participate in the research are busy and their priority is changed due to pandemic Covid-19. 215 samples collected by the author are used in the following analysis in this research.

\section{Analysis}




\subsection{Classic Assumption Test}

Data cleansing is conducted to detect any outlier. The questionnaire is administered to the respondents through online media in which respondents shall respond to all questions to avoid any missing value. Data cleansing used univariate outlier test with Zscore and multivariate outlier test with Mahalanobis Distance. Data with Z-score lower than the cutoff point -3.9 (Ghozali, 2013) was found in Respondent 10 with a minimum Z-score -4.2551. Whereas in multivariate outlier test, the data with Mahalanobis Distance probability beyond the cutoff point 0.001 , also found in Respondent 10 , the value is 0.0000 . Thereby, Respondent 10 was excluded from the research thereby the researcher proceed with 214 respondents.

Table 1 shows respondents' profiles in this research. By their sex, the majority of respondents are male $78.5 \%$. By their age, as much as $60.7 \%$ age $36-45$, while the others are age $25-35$ and above 45 . As many as $53.8 \%$ are staff in their company, and this is the majority position of the respondents. According to the author, this percentage represents the population of this research, where the majority of employees are staff level. By education, the majority are Bachelor / Undergraduate, followed by Master / Graduate as much as $27.1 \%$. $64 \%$ of respondents had 10 years tenure with the company before it is acquired. $78.5 \%$ of respondents had less than 3 years tenure with the acquired company, and $20.1 \%$ had $3-5$ years tenure after the company is acquired. The results show actual population condition, where the companies in this research are acquired in the period 2015-2018, thereby if the research is conducted at the end of 2020 - beginning of 2021, the respondents will work with the acquired company for 2-5 years. The last respondent's characteristic is the respondent's department. This is dominated by the Operations department as much as $34.1 \%$ and also the Subsurface/ Drilling/ Facility department as much as $33.6 \%$.

Table 1. Respondent Profile

\begin{tabular}{|c|c|c|c|}
\hline & & $\begin{array}{l}\text { Frequency } \\
(\mathrm{N}=215)\end{array}$ & $\begin{array}{l}\text { Percentage } \\
\text { (\%) }\end{array}$ \\
\hline \multirow{2}{*}{ Gender } & Man & 168 & $78.5 \%$ \\
\hline & Woman & 46 & $21.5 \%$ \\
\hline \multirow{3}{*}{ Age } & $25-35$ yrs & 46 & $21.5 \%$ \\
\hline & $36-45$ yrs & 130 & $60.7 \%$ \\
\hline & $>45 \mathrm{yrs}$ & 38 & $17.8 \%$ \\
\hline \multirow{4}{*}{ Position } & Staff & 113 & $52.8 \%$ \\
\hline & Supervisor & 67 & $31.3 \%$ \\
\hline & Mid management & 27 & $12.6 \%$ \\
\hline & Top Management & 7 & $3.3 \%$ \\
\hline \multirow{4}{*}{ Level of Education } & High School & 1 & $0.5 \%$ \\
\hline & Diploma/D3 & 17 & $7.9 \%$ \\
\hline & Bachelor/S1 & 138 & $64.5 \%$ \\
\hline & Master/S2 & 58 & $27.1 \%$ \\
\hline \multirow{4}{*}{$\begin{array}{l}\text { Service Year in Previous } \\
\text { Company }\end{array}$} & $<3$ yrs & 17 & $7.9 \%$ \\
\hline & $3-5$ yrs & 16 & $7.5 \%$ \\
\hline & 5-10 yrs & 44 & $20.6 \%$ \\
\hline & $>10$ yrs & 137 & $64.0 \%$ \\
\hline \multirow{3}{*}{$\begin{array}{l}\text { Service Year in Current } \\
\text { Company }\end{array}$} & $1-3$ yrs & 168 & $78.5 \%$ \\
\hline & $3-5$ yrs & 43 & $20.1 \%$ \\
\hline & $>5$ yrs & 3 & $1.4 \%$ \\
\hline \multirow{7}{*}{ Department } & Subsurface/ Drilling/ Facility & 72 & $33.6 \%$ \\
\hline & Operations & 73 & $34.1 \%$ \\
\hline & Planning/ Commercial/ Relations & 13 & $6.1 \%$ \\
\hline & Finance/ Accounting/ IT & 19 & $8.9 \%$ \\
\hline & HR/ Medical & 18 & $8.4 \%$ \\
\hline & Supply Chain/ Facility Management & 9 & $4.2 \%$ \\
\hline & HSSE/ Security & 10 & $4.7 \%$ \\
\hline
\end{tabular}

Source: Data Processing Results 
All variables were tested using descriptive analysis to show descriptive data such as frequency, mean, and standard deviation of the responses to the questionnaire. Table 2 below shows the mean value of Performance as much as 3.697 for the respondents who Agree (4) and the standard deviation is 0.619 . The mean value of the Communication variable is 3.427 for the respondent who Agrees (4) and the standard deviation is 0.711 . The mean value of the Compensation \& Benefits variable is 3.507 for the respondents who Agree (4) and the standard deviation is 0.696 . The mean value of the Motivation variable is 3.336 for the respondents who Agree (4) and the standard deviation is 0.812 .

Table 2. Descriptive Statistics

\begin{tabular}{|l|l|l|l|l|l|}
\hline Variable & N & Min & Max & Mean & Std. Deviation \\
\hline Performance & 215 & 1 & 5 & 3.697 & 0.619 \\
\hline Communication & 215 & 1 & 5 & 3.427 & 0.711 \\
\hline Compensation \& Benefit & 215 & 1 & 5 & 3.507 & 0.696 \\
\hline Motivation & 215 & 1 & 5 & 3.336 & 0.812 \\
\hline
\end{tabular}

Source: Data Processing Results

For validity and reliability tests, all items in the Performance variable are within one dimension and valid with a KMO value above 0.7, and Bartlett's Test of Sphericity significance is 0.000 . The Cronbach's Alpha for Performance is 0.869, and Cronbach's Alpha, if item deleted for all items, is 0.869 . This is to ensure that all Performance items are reliable, therefore all Performance variable items will be used for further analysis. For the Communication variable, KMO is more than 0.7 and the Bartlett Test of Sphericity Sig. is 0.000. This stated that all items of the Communication variable are valid. The Cronbach's Alpha of the analysis results is 0.946 and the Cronbach's Alpha if item deleted for all items is less than 0.946 therefore it shows that all items of the Communication variable are reliable. In Compensation \& Benefit, there is one item that makes this variable is not valid and reliable, which is item COM-7. By excluding the item, the KMO value of the Compensation \& Benefits variable is 0.855 or above 0.7 with the Bartlett Test of Sphericity Sig. as much as 0.000 which shows that the Compensation \& Benefit variable is valid. Whereas for the reliability test, the Cronbach's Alpha of Compensation \& Benefit variable after item COM-7 excluded is 0.888 from 0.880, the Cronbach's Alpha, if item deleted, is less than 0.888 , therefore, it shows that all items of Compensation \& Benefit variable had become reliable. The next test for the Motivation variable, KMO value is larger than 0.7 and the Bartlett Test of Sphericity Sig. as much as 0.000 that all items of Motivation variable are valid. The Cronbach's Alpha of the Motivation variable is 0.945, which stated that all items are reliable. From these results, all remaining items of Performance, Communication, Compensation \& Benefits, and Motivation variables will be included in further analysis.

The author then conducted a normality test. The first normality test is by descriptive analysis to shows its statistic skewness and curtosis, where all variables are less than 1.96, followed by a univariate test of Kolmogorov-Smirnov from its results which shows that the value for each variable is larger than 0.05 thereby it is stated that the six variables data followed normality assumption. In a multivariate test, a histogram shows the data distribution of bell-shaped and a P-P plot shows data distribution is in line and dense with a line in the center, thereby the data in this research is normal. A multicollinearity test is conducted to ensure that a regression model is multicollinear or intercorrelated between independent variables. Findings show that the data set is free of multicollinearity with the VIF value of all variables being less than 10 and the tolerance being above 0.1 . The next classic assumption test is the linearity test which shows that the linearity between the dependent variable Performance and the other two dependent variables Communications, Compensation \& Benefits and Motivation has a significance value less than 0.05 which means that it follows linearity.

\subsection{Hypothesis Test Results}

\subsubsection{Path Analysis for Communication and Compensation \& Benefits, and Motivation on Performance Variables}

The following is path analysis for Communication and Motivation on Performance variables and path analysis for Compensation $\&$ Benefits and Motivation on Performance Variables. 
Table 3. Path Analysis for Communication and Compensation \& Benefit Variables, and Motivation on Performance (Output Coefficients)

\begin{tabular}{|c|c|c|c|c|c|}
\hline \multirow{2}{*}{ Model } & \multicolumn{2}{|c|}{ Unstandardized Coefficients } & \multirow{2}{*}{$\begin{array}{l}\text { Standardized Coefficients } \\
\text { Beta }\end{array}$} & \multirow{2}{*}{$\mathrm{t}$} & \multirow{2}{*}{ Sig } \\
\hline & $\mathrm{B}$ & Std. Error & & & \\
\hline \multicolumn{6}{|c|}{ Communication on Performance (Output Coefficients) } \\
\hline (Constant) & 1.436 & 0.137 & & 10.49 & 0.000 \\
\hline KOM & 0.66 & 0.039 & 0.757 & 16.867 & 0.000 \\
\hline \multicolumn{6}{|c|}{ Communication on Motivation (Output Coefficients) } \\
\hline (Constant) & 0.933 & 0.217 & & 4.305 & 0.000 \\
\hline KOM & 0.701 & 0.062 & 0.614 & 11.313 & 0.000 \\
\hline \multicolumn{6}{|c|}{ Communication and Motivation on Performance (Output Coefficients) } \\
\hline (Constant) & 1.182 & 0.129 & & 9.155 & 0.000 \\
\hline KOM & 0.469 & 0.045 & 0.538 & 10.467 & 0.000 \\
\hline MOT & 0.272 & 0.039 & 0.357 & 6.944 & 0.000 \\
\hline \multicolumn{6}{|c|}{ Compensation \& Benefits on Performance (Output Coefficients) } \\
\hline (Constant) & 1.732 & 0.156 & & 11.115 & 0.000 \\
\hline $\mathrm{COM}$ & 0.562 & 0.044 & 0.663 & 12.887 & 0.000 \\
\hline \multicolumn{6}{|c|}{ Compensation \& Benefits on Motivation (Output Coefficients) } \\
\hline (Constant) & 1.145 & 0.225 & & 5.082 & 0.000 \\
\hline COM & 0.627 & 0.063 & 0.564 & 9.935 & 0.000 \\
\hline \multicolumn{6}{|c|}{ Compensation \& Benefits and motivation on Performance (Output Coefficients) } \\
\hline (Constant) & 1.330 & 0.143 & & 9.330 & 0.000 \\
\hline COM & 0.343 & 0.046 & 0.404 & 7.506 & 0.000 \\
\hline MOT & 0.350 & 0.041 & 0.459 & 8.538 & 0.000 \\
\hline \multicolumn{6}{|c|}{ Motivation on Performance (Output Coefficients) } \\
\hline (Constant) & 1.949 & 0.131 & & 14.911 & 0.000 \\
\hline MOT & 0.524 & 0.038 & 0.687 & 13.765 & 0.000 \\
\hline
\end{tabular}

Source: Data Processing Results

Table 3 findings show that Performance is significantly and directly correlated to the Communication variable with Sig value is 0 $(<0.05)$ and t-value < t-table $(16.687>1.98)$. After which the author looks at the Communication capability in correlation to Motivation. Motivation is significantly and directly correlated to Communication variable with Sig value is $0(<0.05)$ and $t-v a l u e ~>$ t-table $(11.313>1.98)$. After which the author conducts regression to both variables where the Motivation is the mediation variable between the Communication variable to the Performance. In the table shown a partial correlation of the Communication variable is significant with Beta Coefficient 0.538, which means there is a direct correlation from Communication to the Performance. In addition, the correlation of Motivation to Performance is also significant with a t value $=6.944(>1.98)$ and the Sig value is 0 $(<0.05)$. From the path analysis to the Communication variable on Performance, it can be concluded that Communication together with Motivation is correlated to Performance.

Table 3 also shows if Compensation \& Benefits variable is significantly and directly correlated the Performance with Sig value is 0 $(<0.05)$ and t-value $>$ t-table $(12.887>1.98)$. Furthermore, the author observes the correlation of the Compensation $\&$ Benefits variable to the Motivation. The table also shows if the Compensation \& Benefits is significantly and directly correlated to the Motivation with Sig value is $0(<0.05)$ and t-value $>$ t-table $(9.935>1.98)$. After which the author conducts regression to both variables where the Motivation is the mediation variable between the Communication variable to the Performance. The Compensation \& Benefits variable is partially correlated with t-value > t-table $(7.506>1.98)$ and the Beta Coefficient is 0.404 it can be interpreted as significant. Findings show a direct correlation from the Compensation \& Benefits to the Performance. In addition there is correlation between the Motivation to the performance with t value $=8.538(>1,98)$ and Sig value is $0(<0.05)$. 
The conclusion from path analysis to the Compensation \& Benefits variables on Performance which is Compensation $\&$ Benefits variables together with Motivation is correlated to the Performance.

Motivation variable significantly and directly correlated on the Performance with Sig value is $0(<0.05)$ and t-value $>\mathrm{t}$-table $(13.765$ $>$ 1.98). The author did not conduct the Motivation capability simultaneously, but it will be tested by the Sobel test to see Motivation capability as the intervening variable.

To find the significance of direct and indirect correlation of each variable, it is necessary to calculate Beta Coefficient on the Standardized Coefficients for each variable.

a) Direct Correlation

The calculation of each independent variable for its direct correlation is shown in the following table.

Table 4. Direct Correlation of Communication and Compensation \& Benefits to the Performance

\begin{tabular}{|l|l|l|l|l|l|}
\hline $\begin{array}{l}\text { Independent } \\
\text { Variable }\end{array}$ & Direct Effect & Coef. a & $\begin{array}{l}\text { Coef. } \\
\text { b }\end{array}$ & Coef. c' & Sig \\
\hline \multirow{2}{*}{$\begin{array}{l}\text { Communication } \\
(\text { KOM })\end{array}$} & Communication on Motivation $(X \rightarrow Z)$ & 0.701 & & & 0.000 \\
\cline { 2 - 6 } & Motivation on Performance $(Z \rightarrow Y)$ & & 0.272 & & 0.000 \\
\cline { 2 - 6 } & Communication on Performance $(X \rightarrow Y)$ & & & 0.469 & 0.000 \\
\hline \multirow{2}{*}{$\begin{array}{l}\text { Compensation } \\
\text { Benefit }(C O M)\end{array}$} & Comp. \& Benefits on Motivation $(X \rightarrow Z)$ & 0.627 & & & 0.000 \\
\cline { 2 - 6 } & Motivation on Performance $(Z \rightarrow Y)$ & & 0.35 & & 0.000 \\
\cline { 2 - 6 } & Comp. \& Benefits on Performance $(X \rightarrow Y)$ & & & 0.343 & 0.000 \\
\hline
\end{tabular}

Source: Data Processing Result

b) Indirect Correlation/ coefficient ab.

The correlation of each independent variable on Performance mediated by Motivation:

1. Communication Variable, $X \rightarrow Z \rightarrow Y=(0.701 \times 0.272)=0.190$

2. Compensation \& Benefit Variable, $X \rightarrow Z \rightarrow Y=(0.627 \times 0.350)=0.219$

c) Total Correlation / coefficient c

1. Communication Variable, $X \rightarrow Z \rightarrow Y=(0.701+0.272)=0.971$

2. Compensation $\&$ Benefit Variable, $X \rightarrow Z \rightarrow Y=(0.627+0.350)=0.977$

Referring to direct correlation results of mediation model from $X$ to $Y$ (coefficient $c^{\prime}$ ), the conclusion that can be inferred is there is a significant correlation on Communication variable to the Performance and also Compensation \& Benefits variable to the Performance and each has Sig value $0(<0.05)$.

From the calculation and acceptance criteria that a variable is a mediation variable, it can be concluded that the mediation criteria for the Communication variable are accepted where Sig $<0.05$. The correlation of coefficient $c^{\prime}$ as much as 0.469 with Sig $0<0.05$ and lower ab coefficient 0.190 but not equal to zero and having mediation element, therefore findings shows partial mediation by the Motivation. This applies to the mediation criteria where the Compensation \& Benefits variable is accepted with $\mathrm{Sig}<0.05$. The correlation of coefficient $c^{\prime}$ as much as 0.343 with Sig $0<0.05$ and lower ab coefficient as much as 0.219 but not equal to zero and having mediation element, therefore findings show partial mediation by the Motivation.

To find the significance of the indirect correlation of Communication and Compensation \& Benefits to Performance, the author conducts the Sobel test to the Product of Coefficient strategy. This Product of the Coefficient strategy is considered as having statistical capability than any other official method which includes Baron and Kenny method (Preacher and Hayes, 2004). Below is the equation used in the Sobel test: 


$$
S a b=\sqrt{b^{2} S a^{2}+a-S b^{2}+S a^{2} b^{2}}
$$

Description:

a: independent variable coefficient

b: mediation variable coefficient

Sa: a coefficient standard deviation

Sb: b coefficient standard deviation

Significance test for indirect correlation of independent variable to the dependent variable, it is conducted by calculation of ab coefficient $z$ score using the formula $\mathbf{z}=\mathbf{a b} / \mathbf{S a b}$, where the calculation of each variable use Sobel Test which is Communication variable with $Z$ score (5.935) > 1.96 ( $z$ score is absolute) there is a significant indirect correlation of Communication to the Performance. This applies to the Compensation \& Benefits variable with a Z score (6.479) $>1.96$, there is a significant indirect correlation of Communication \& Benefits to the Performance.

The research hypotheses from causal step and product of coefficient is that from the findings shown in Table 3 where the significance value of Communication, Compensation \& Benefits variables is below 0.05, it can be concluded that $\mathbf{H} \mathbf{1}$ is accepted, which means that Communication has a significant correlation on the Employees Performance. This means the communication process could have a significant correlation on the employee's performance, especially during the transition when the surviving company commenced its operation after acquisition. $\mathbf{H} \mathbf{2}$ is accepted, which means that Compensation \& Benefits has a significant correlation on the Employees Performance. Compensation \& Benefits are seen as important for the employees which might affect overall performance. $\mathbf{H} \mathbf{3}$ is accepted, which means that Motivation has a significant correlation with Employees Performance.

Based on the Sobel test, where z score of the two independent variables $>1.96$ and from direct, indirect, and total correlation test where analysis results show that Motivation has partial mediation on Communication and Compensation \& Benefits to the Performance, it can be concluded that $\mathbf{H 4}$ is accepted, means that Communication mediated by Motivation could affect the Employees performance. This also applies to the last hypothesis $\mathbf{H 5}$ is accepted, which means that Compensation \& Benefits mediated by Motivation could affect the Employees Performance.

\subsection{Analysis Discussion}

The purpose of this research is to see whether communication and compensation \& benefits are correlated to the employee's performance in the surviving company after the M\&A process, also whether the variables are correlated to the motivation as a mediation variable.

Hypothesis 1 and Hypothesis 4 test shows that communication has a significant correlation with the employee's performance and such correlation is mediated partially by motivation. In general, the satisfactory level of communication from the company to the respondents is $53 \%$ of the total respondent. From the number, it is proved that communication has a significant role in the development of employees confidence level towards the company. In this research, the relatively low communication satisfaction level towards the company shall be highlighted by the company especially by the top management, where they need to improve further their communication and engagement to the employees, and need to develop a communication package both direction and report which shall be clear, brief and meaningful. It is acknowledged that at the beginning of the transaction almost all administrative procedures are changed according to the surviving company, however, after which, information and communication shall be provided inconsistent manner and empiric as well as in writing, therefore it is accessible and followed by all employees.

This research support previous research by So et. al. (2018) which stated that a company's internal communication has a significant correlation with employees' performance. Communication shall be constantly carried out and thereby, it is encouraged that the company shall maintain such communication process because its effect on employees' performance had been proven. In addition, research by Ardiansyah (2016) on a company in East Java previously had shown communication direct positive correlation on employees performance. This research findings and the supporting researches support the research by Robbins (2006) who stated that communication support motivation by a clear presentation on what employees shall do, how they should do it properly, and what shall be completed to improve their achievement below standard. Findings in Sarini et al. (2020) presented reversed results to this research where motivation did not mediate the communication variable to the employee's performance because the company shall develop its communication process to effectively deliver messages. Positive motivation is expected will improve ineffective communication. However, other research by Sarido and Soliha (2016) supports this research finding, which stated that motivation mediates the communication correlation on employees' performance. With positive employees motivation, it is 
correlated to excellent performance and improve it. Thereby, excellent company communication is correlated to motivation, initially at peers level, later to their performance.

Hypothesis 2 and Hypothesis 5 results show that compensation \& benefits are significantly correlated to the employee's performance, and such correlation is partially mediated by motivation. The author did not highlight the compensation factor as only cash compensation but also the benefits received by the employees such as health insurance, loan (for housing), bonuses, and other benefits. This is the task of the company's management to maintain compensation $\&$ benefits according to the market and position and level of employees capability and their contribution to the company. In general, there are respondents who perceived that their compensation \& benefits are satisfactory, whereas some others expect appropriation. This is related to the transition process and employees mapping within the first 3 years after acquisition. The compensation $\&$ benefits at the initial stage of acquisition is the scheme applied by the acquired company.

Pratama et al.'s (2015) research show comparable findings that compensation \& benefits significantly correlated to the employee's performance and the larger compensation received by the employee, the higher their performance, on the contrary, the lower compensation, the lower performance. This research also supports the research by Abdul Kadir et al., (2019) that compensation \& benefits are significantly correlated to the employee's performance. Employees' performance contribution shows important for the company's success and thereby, to develop employees' performance, the company shall prepare effective plans and strategies such as compensation \& benefits strategy. Sarido and Soliha (2016) in the previous research shows that motivation has mediation effect on the correlation of compensation to performance. It stated that compensation as a monetary reward and real benefits given by the company to its employees supports of contract and proportional and fair compensation will create motivation on each employee. Compensation and benefits are perceived as employees' objectives and it would affect their performance. Research by Candradewi \& Dewi (2019) also support that compensation has a significant and positive correlation on motivation, whilst motivation has a significant and positive correlation on employees' performance, and compensation has a significant and positive correlation on employees' performance with mediation. These findings show that motivation mediated the correlation of compensation on employees' performance. Higher compensation could affect employees' motivation and improve employees' performance. However, this did not support findings by Maria (2019) that motivation did not mediate the relationship between compensation $\&$ benefits to the employee's performance.

Hypothesis 3 results show that motivation has a significant correlation with employees performance. This research placed motivation as a mediation variable, but motivation itself has no direct positive correlation on employees' performance, where employees' performance is better if they have strong motivation to work. As stated in the foregoing, motivation is an important element for an organization to achieve its objectives or success, and the individual motivation of each employee could also be empowered by the company's management through nurturing environment and conducive for its employee's motivation.

Farhah et al. (2020) research findings support this research, it stated that motivation has a direct significant correlation on employees' performance thereby higher level of employees performance is needed to motivate or empower the employees. These research findings also support research by Purwanto (2020) where the motivation variable as an independent variable has a positive and significant correlation on employees' performance. An employee can have motivation both extrinsic and intrinsic to perform a particular task. Both motivation concepts are empowered each other, but there are times intrinsic motivation is weakened by extrinsic motivators. In addition, any individual will have different motivations, few are motivated extrinsically, and the rest are intrinsically motivated. So et. al. (2018) conduct research in which findings stated that motivation has a significant correlation with employees' performance, that positive motivation will improve their performance.

\section{Conclusion and Recommendation}

The research is conducted by the author to examine the correlation of independent variables such as Communication and Compensation \& Benefits on the Performance as the dependent variable, in addition, this research examines Motivation mediation effect on such variables to the Performance. This research targeted four oil and gas companies in Indonesia after acquisition within the period 2015-2018. In general, the conclusion of this research stated that employees' performance in particular those who work in the oil and gas industry of the companies after the acquisition is significantly correlated to the company's communication, as well as the compensation and benefits received by the employees. Motivation is a mediator which empowers the relation between communication and compensation \& benefits to overall employees' performance.

In its communication, the company shall maintain and develop effective communication, thus its employees will be updated on the latest news/issues with respect to the company. This shall be carried out to maintain the involvement and engagement and the sense of belonging to the company. The more employees are involved in any activity towards the company's objectives, the more confident and responsible they are to show maximum contribution for the company. The company shall maintain or renew 
and appropriate the compensation \& benefits received by the employees according to the market in the industry. This is the company's responsibility to its employees. The employees who perceived that the compensation $\&$ benefits as received by them are as expected, they will be hard to be persuaded to work for other companies. Reward also will improve employees' performance no matter how peculiar, this will maintain employees motivation.

The variables in this research are two variables with the potential to affect the employee's performance, and only have one mediation variable which is motivation. Findings shows, the variables could not fully explain all factors with potential effects on performance, especially in the oil and gas industry in Indonesia. With this said, other variables might have potential effects on employees' performance.

\section{References}

[1] Abdul K, A \& AlHosani, A. (2019). The Effect of Compensation and Benefits Towards Employee Performance. DOI: 10.4108/eai.30-72019.2287551.

[2] Abdulsalam, D., \& Mawoli, M. A. (2012). Motivation and Job Performance of Academic Staff of State Universities in Nigeria: The Case of Ibrahim Badamasi Babangida University, Lapai, Niger State. International Journal of Business and Management, 7(14), 142.

[3] Aktar, S., Sachu, M. K., \& Ali, M. E. (2012). The Impact of Rewards on Employee Performance in Commercial Banks of Bangladesh: An Empirical Study. IOSR Journal of Business and Management, 6(2), 9-15.

[4] Amah, E. (2016). Internal Organizational Communication and Employees' Performance in Selected Banks in Port Harcourt. International Journal of Novel Research in Humanity and Social Sciences. Vol. 3, Issue 3: 86-95.

[5] Andreani F. \& Petrik A. (2016). Employee Performance as The Impact of Transformational Leadership and Job Satisfaction in PT Anugerah Baru Denpasar. JMK, VOL. 18(1), 25-32.

[6] Ardiansyah, D.O. (2016). Pengaruh Komunikasi Terhadap Kinerja Karyawan Dengan Dimediasi oleh Kepuasan Kerja. Jurnal Bisnis dan Manajemen Vol. 3 No. 1, January 2016.

[7] Bhatia, K \& Balani, M. (2015). Effective Internal Communication: A Crucial Factor Affecting Employee Performance. Proceedings of International Conference on Management, Economics and Social Sciences. ISBN: 9788193137321

[8] Candradewi, I. \& Dewi, I G A M. (2019). Effect of Compensation on Employee Performance towards Motivation as Mediation Variable. International Research Journal of Management, IT \& Social Sciences. 6 (5), 134-143.

[9] Chintallo, S \& Mahadeo, J. (2013). Effect of Motivation on Employees' Work Performance at Ireland Blyth Limited. Proceedings of 8th Annual London Business Research Conference Imperial College. London, UK. ISBN: 978-1-922069-28-3

[10] Dessler, G. (2006). Human Resource Management, (10th Edition). Paramita Rahayu Translation, Jakarta.

[11] Duff \& Phelps Singapore Pte Ltd. (2016). Transaction Trail Annual Issue 2016.

[12] Farhah, A \& Ilham, M. (2020). Pengaruh Motivasi Kerja Dan Disiplin Kerja Terhadap Kinerja Karyawan. Jurnal Online Program Studi Pendidikan Ekonomi. 5. 1. DOI: 10.36709/jopspe. v5i1.13326.

[13] Ge, Q. \& Cao, H.M. (2014). Enterprise Merger of Human Resources Integration Problems Probing. Journal of Human Resource and Sustainability Studies, 2, 27-32.

[14] Ghosh, A. and B. Das. (2003). Mergers and Takeovers. The Management Accountant, 38(7), 543-545.

[15] Ghozali, I. (2013). Aplikasi Analisis Multivariate dengan Program IBM SPSS 21 Update PLS Regresi. Semarang: Badan Penerbit Universitas Diponegoro

[16] Hamali, A. Y. (2018). Pemahaman Sumber Daya Manusia. Yogyakarta: PT Buku Seru.

[17] Hameed, A., Ramzan, M., \& Zubair, H. M. K. (2014). Impact of compensation on employee performance (empirical evidence from banking sector of Pakistan). International Journal of Business and Social Science, 5(2).

[18] Hanafi, B. D., \& Yohana, C. (2017). Pengaruh Motivasi, Dan Lingkungan Kerja, Terhadap Kinerja Karyawan, Dengan Kepuasan Kerja Sebagai Variabel Mediasi Pada PT BNI Life Insurance. Jurnal Pendidikan Ekonomi Dan Bisnis (JPEB), 5(1), 73-89.

[19] Hee, O \& Qin, D. (2019). Exploring the Impact of Communication on Employee Performance. International Journal of Recent Technology and Engineering. 8. 10.35940/ijrte.C1213.1083S219.

[20] Kiruja, E.K., \& Mukuru, E. (2018). Effect of Motivation on Employee Performance in Public Middle-Level Technical Training Institutions in Kenya. International Journal of Advances in Management and Economics, 2(4), 73-82.

[21] Kivuti, M. (2013). The influence of mergers and acquisitions on employee performance: a case of Equatorial Commercial Bank.

[22] Maduka, C.E., \& Okafor, O.C. (2014). Effect of Motivation on Employee Productivity: A Study of Manufacturing Companies in Nnewi. International Journal of Managerial Studies and Research (IJMSR), 2(7), 137-147.

[23] Mangkunegara, A. P. (2005). Manajemen Sumber Daya Manusia Perusahaan. Bandung. PT Remaja Rosdakarya.

[24] Maria, E. (2019). The Influence of Organizational Culture, Compensation and Interpersonal Communication in Employee Performance Through Work Motivation as Mediation. International Review of Management and Marketing, 2019, 9(5), 133-140.

[25] Muchiti, E. \& Gachunga, H. (2015). Influence of Work-Life Balance on Employee Productivity in Kenya; A case Of Milimani Law Courts Nairobi. JKUAT, Kenya. Vol. 2.

[26] Muda, I., Rafiki, A \& Harahap, M. (2013). Factors Influencing Employees' Performance: A Study on the Islamic Banks in Indonesia. International Journal of Business and Social Science, 5(2).

[27] Mwebi, M.B \& Kadaga M.N. (2015). Effects of Flextime Work Arrangement on Employee Performance in Nairobi CBD Commercial Banks International Journal of Novel. Research in Marketing Management and Economics Vol. 2.

[28] Poddar, N. (2019). A Study on Mergers and Acquisition in India and Its Impact on Operating Efficiency of Indian Acquiring Company. Theoretical Economics Letters, 09(04), 1040-1052. 
[29] Pratama, S. A., Hakam, M. S., Nurtjahjono, G.E. (2015). Pengaruh Kompensasi Terhadap Kinerja Karyawan. Jurnal Administrasi Bisnis (JAB) Vol. 25 No 1, Agustus 2015.

[30] Purwanto, K. (2020). Pengaruh Motivasi Kerja Terhadap Kinerja Pegawai. International Journal of Management and Business, Vol. 1 No. 1 (2020), 31 - 36. ISSN Media Elektronik: 2722-4953.

[31] Robbins, S. P., Sanghi, S. (2006). Organizational Behavior (11th Ed.). Delhi: Dorling Kindersley (India) Pvt. Ltd.

[32] Samnani, A.-K., \& Singh, P. (2014). Performance-enhancing compensation practices and employee productivity: The role of workplace bullying. Human Resource Management Review, 24(1), 5-16.

[33] Sarido, S., E. (2016). Pengaruh Komunikasi dan Kompensasi Terhadap Kinerja Pegawan Dengan Motivasi Dan Komitmen Organisasional Sebagai Mediasi. Telaah Manajemen Vol.13 Edisi 2, Oktober 2016, 119-134.

[34] Sarini, W, M.F., Syamsudin, I, M. (2020). The Role of Motivation as Mediation in the Relationship between Communication and Work Discipline on Employee Performance. Issues on Inclusive Growth in Developing Countries, 1 (02) 2020, 93 - 104.

[35] Shahzadi, I., Javed, A., Pirzada, S.S., Nasreen, S., Khanam, F. (2014). Impact of Employee Motivation on Employee Performance. European Journal of Business and Management, 6(23).

[36] So, G.I, Noerlina, Djunggara, A.A., Fahrobi, R., Simamora, B. H., Ruangkanjanases. (2018). Effect of Organisational Communication and Culture on Employee Motivation and Its Impact on Employee Performance. Social Sciences \& Humanities. Pertanika J. Soc. Sci. \& Hum. 26 (2): $1133-1142$.

[37] Sosrowidigdo, S. (2020). The Influence of Organizational Communication Toward Employee Performance in P.T. Pos Indonesia East Jakarta Branch. Journal of Research in Business, Economics, and Education. E-ISSN 2686-6056

[38] Tanriverdi, H. (2005). Knowledge Relatedness and the Performance of Multibusiness Firms. Strategic Management Journal, 26(2), 97-120.

[39] Tegos, M. (2016). Tech leads investment in Singapore, Malaysia, and Indonesia in 2016 despite the slowdown.

[40] Timmerman, A. (2017). Indonesia 2016: Riding on inbound deals, M\&A activity sees big recovery.

[41] Widiani, N. P., Putri, A. M. A. D., Sari, M. M. R., \& Wirajaya, I. G. A. (2019). The Effect of Love of Money and Emotional Intelligence on Employee Performance with Organizational Citizenship Behavior As Mediating Variable. International Research Journal of Engineering, IT \& Scientific Research, 5(1), 39-49. 